\title{
The Antecedence of Teacher's Professional Performance: Evidence from Indonesia
}

\author{
M. Mawarto ${ }^{1, *}$, W. Widodo ${ }^{2}$, S. Sulistiasih ${ }^{3}$ \\ ${ }^{1}$ Bumiputra College of Economics Science, Jakarta, Indonesia \\ ${ }^{2}$ Faculty of Education and Social Sciences, Indraprasta University, Jakarta, Indonesia \\ ${ }^{3}$ Faculty of Psychology, Bayangkara University, Jakarta, Indonesia
}

Received July 2, 2020; Revised July 30, 2020; Accepted September 11, 2020

\section{Cite This Paper in the following Citation Styles}

(a): [1] M. Mawarto, W. Widodo, S. Sulistiasih, "The Antecedence of Teacher's Professional Performance: Evidence from Indonesia," Universal Journal of Educational Research, Vol. 8, No. 10, pp. 4760 - 4768, 2020. DOI: 10.13189/ujer.2020.081047.

(b): M. Mawarto, W. Widodo, S. Sulistiasih (2020). The Antecedence of Teacher's Professional Performance: Evidence from Indonesia. Universal Journal of Educational Research, 8(10), 4760 - 4768. DOI: 10.13189/ujer.2020.081047.

Copyright $\subseteq 2020$ by authors, all rights reserved. Authors agree that this article remains permanently open access under the terms of the Creative Commons Attribution License 4.0 International License

\begin{abstract}
Teacher professionalism determines the quality of education output. Hence, this study aims to explore the effect of good corporate governance (GCG) and knowledge management $(\mathrm{KM})$ on the teacher's professional performance in Indonesia mediating by affective commitment. A questionnaire collected the research data through the survey method. The research participants are 375 teachers spreading across three provinces (Jakarta, Banten, West Java) determined by accidental sampling. Data analysis uses path analysis supported by descriptive statistics. The results show that GCG and KM have a significant effect on the teacher's professional performance, either directly or indirectly, mediating by affective commitment. The affective commitment has a direct effect more adequate on the teacher's professional performance than GCG and KM, $\mathrm{KM}$ has a direct effect more adequate on teacher's affective commitment than GCG, and KM has an indirect effect more appropriate on the teacher's professional performance mediated by affective commitment than GCG. Therefore, a fit research model about the effect of GCG and $\mathrm{KM}$ on the teacher's professional performance mediated by affective commitment was found based on data from teachers in Indonesia. This model can be adopted as a reference or discursus by researchers and education practitioners in developing teacher professional performance models in the future and various contexts, fields, and educational organizations.
\end{abstract}

Keywords GCG, Knowledge Management, Affective
Commitment, Professional Performance

\section{Introduction}

The teacher's professional performance is often disputed when schools lack or even fail to play their role as learning organizations, indicating that students cannot absorb various subject matter with optimal results. As stated, Hoy and Miskel [1], schools - in contrast to other types of organizations - must become learning organizations. Hence, school should become places where students (members of the organization) continually expand their skills to create and achieve, places to encourage new patterns of thinking, places collective aspirations are learned, where students (members of the organization) learn how to learn together, and where organizations expand their ability to innovate and solve problems [2]. Performance refers to a set of tasks or work behaviors designed to accomplish job requirements or realize organizational goals [3]-[5]. According to Daft [6], performance relates to the organization's ability to attain its goals using resources efficiently and effectively manner. Professionalism is reflecting an ideal that becomes the goal of individuals and group work aspiring to distinguish themselves from other workers [7]. Professionalism also means an exclusive means of organizing work and controlling workers [8]. Besides, professionalism is a 
center of values related to altruism, caring, honor, integrity, and duty, and speaking of the emergence of these values centers as a representation of behavior related to professionalism, such as respect, accountability, empathy, and affection [9]. Grady, Helbling, and Lubeck [10] add that afrofessional also exercises wisdom in making decisions within the scope of his expertise, and takes some authority for his professional development. Glickman, Gordon, and Ross-Gordon [11] state that stages of professional development typically involve three steps of learning, which are orientation, integration, and refinement. Therefore, professional performance is a set of tasks or work behaviors designed to accomplish a job requirement or realize organizational goals conducted with respect, accountability, empathy, and affection.

Has-been as a quote by Rulandari [8] argue that professional teachers must have the following requirements, which are: (1) teaching skills - to educate, teach, guide, instruct and transfer knowledge; (2) communication skills - both oral and written effectively, such as good writing, clear voice, and understandable words; (3) personality authority - in the execution of duty, have a pleasant personality, recognizable abilities, and skills; (4) social skills - the are proficiency in the social field to secure the trust and loyalty, helpful, objective and willing to learn and able to respect the other people's opinion; (5) technical competence - should be theoretical and technical competencies and at the same time become excellent problem solver); and (6) emotional stability should not prejudice to the task in hand, should not be quick-tempered, but develop openness, and objective values. Based on several research and studies in various countries, industrial, occupational sectors, and organizations, professional performance among others influenced by GCG, KM, and affective commitment.

\section{Literature Review and Hypothesis Development}

\subsection{GCG and Professional Performance}

GCG is a combination of processes and structures implemented by the company to inform, direct, manage, and monitor the organization activities towards achieving its objectives [12]. According to The Cadbury Report as a quote Lukviarman [13], corporate governance is concerned with maintaining the balance between economic and social goals and between individual and communal goals. The governance framework is there to encourage the efficient use of resources and equally to require accountability for the stewardship of those resources. The aim is to align as nearly as possible the interest of individuals, corporations, and society. GCG refers to a system that regulates and controls the company to create added value for each stakeholder. True information is accurate and timely, and the company's obligation to transparently disclose all information on company performance, ownership, and stakeholders must be carried out by company management [14][15]. Hence, GCG needs a governance mechanism, like formal methods or informal relations used to control the behavior, nourish cooperation, and govern the relationship of various participants [16]. GCG consists of five main principles as indicators, namely transparency, accountability, responsibility, independence, and fairness [17]. If the principles can be well-conditioned by the organization, authority potentially stimulates enhancing professional performance. The studies by scholars proved that GCG affects professional performance [18]-[23]. Based on arguments and studies above, the first hypothesis in this study is:

$\mathbf{H}_{1}$ : GCG had a direct effect on professional performance.

\subsection{KM and Professional Performance}

The present knowledge grows up became a need. Everyone, groups, organizations, and nations need knowledge. Hence, knowledge is essential to manage. That is the reason why $\mathrm{KM}$ always becomes an interesting issue among scholars and practitioners. KM is about making sure that knowledge from employees, teams, and units in an organization is captured, remembered, stored, and shared with others [24]. KM is concerned with storing and sharing the wisdom, understanding, and expertise accumulated in an organization about its processes, techniques, and operations [25]. Therefore, KM works as a process of enhancing company performance by using tools, processes, systems, and cultures to improve the creation, sharing, and use of knowledge [26]. KM involves recognizing, generating, documenting, distributing, and transferring among persons useful information, know-how, and expertise to improve organizational effectiveness [27]. With conditions like that, KM requires developing a system for collecting and maintaining data, information, experiences, and lessons, as well as improving communication [28]. KM consists of 10 principles of knowledge in which emphasizes the people, process, and conceptual. The people principles related to the recognition that implementation of KM is very political for finding a person to be the official knowledge managers for an organization, that using knowledge and sharing it are not easy or natural, and KM requires hybrid solutions of people and technology. The process principles recognize that KM involves improving or transforming existing knowledge work process, providing people with access to knowledge is only the beginning of $\mathrm{KM}$, and that $\mathrm{KM}$ is never finishing because knowledge is continually changing and evolving. The conceptual principles recognize that $\mathrm{KM}$ is very expensive, requires a knowledge contract, a constitutional recognition of the thorny concept of intellectual property [29]. These principles can manage to 
increase professional performance potentially. The various research carried out by researchers also revealed that KM influences professional performance [30]-[39]. Based on arguments and studies above, the second hypothesis in this study is:

$\mathbf{H}_{2}$ : KM had a direct effect on professional performance.

\subsection{Affective Commitment and Professional Performance}

Commitment is the degree to which an employee identifies with the organization and wants to continue actively participating in it, willing to put forth effort on its behalf [40][26]. Commitment also reflected as a force that binds an individual to a course of action of relevance to one or more targets, reliable identification of someone with their duties, and self-identification, loyalty, and involvement expressed by someone [41]-[43]. In organizations context, organizational commitment is the extent to which an individual identifies with an organization and its goal, manifested in day-to-day work activity [43][44]. Organizational commitment also refers to employees' desire to remain members of the organizations and state of employees who side with an organization and its goals and want to maintain its membership in the organization [44][45]. Organizational commitment, among others, affective commitment, which involves the employees' emotional attachment to, identification with, and involvement in the organization [46]. For Newstrom [40], affective commitment is the employees' positive emotions to try and choose to remain part of the organization. Like the arguments, Ivancevich, Konopaske \& Matteson [3] state that commitment involves many attitudes reflected affection, such as feelings are identical to organizational goals, a sense of being involved in organizational tasks, and feeling loyal to the organization. The teachers with adequate affective commitment tend to optimally professional performance, manifested in teaching skills, communication skills, personality authority, social skills, technical competence, and emotional stability. Several studies also concluded that affective commitment influences professional performance [47]-[55]. Based on arguments and studies above, the third hypothesis in this study is:

$\mathbf{H}_{3}$ : Affective commitment had a direct effect on professional performance.

\subsection{GCG and Affective Commitment}

Affective commitment besides influences professional performance also affected GCG. The principles of GCG, for instance, transparency, accountability, responsibility, independence, and fairness [17] can be conditioned entirely by the organization authority potentially stimulate increasing affective commitment, which involves the employees' emotional attachment to, identification with, and involvement in the organization [46]. The investigation by researchers also approved that GCG affects affective commitment [56][57]. Based on the statements and studies above, the fourth hypothesis in this study is:

$\mathbf{H}_{\mathbf{4}}$ : GCG had a direct effect on affective commitment

\subsection{KM and Affective Commitment}

KM also influences affective commitment. The principles of KM, which concern the people, process, and concept, can be excellence conditioned to potentially increase affective commitment, which involves the employee's emotional attachment to, identification with, and involvement in the organization [46]. The studies conducted by scholars in various contexts and organizations also indicated that $\mathrm{KM}$ affects affective commitment [58]-[61]. Based on the statements and reviews above, the fifth hypothesis in this study is:

$\mathbf{H}_{5}$ : KM had a direct effect on affective commitment

\subsection{GCG and Professional Performance Mediating by Affective Commitment}

The Affective commitment can role mediates the effect of GCG on professional performance. The principles of GCG, such as, transparency, accountability, responsibility, independence, and fairness [17] can be conditioned entirely by the organization authority can be stimulated affective commitment, which involves the employees' emotional attachment to, identification with, and involvement in the organization [46]. It implies to increase professional performance reflected in teaching skills, communication skills, personality authority, social skills, technical competence, and emotional stability. The studies carried out by research approve that GCG affects affective commitment [56][57], while the other studies conducted scholars concluded that affective commitment affects professional performance [47]-[55]. Based on argues and studies above, the sixth hypothesis in this study is:

$\mathbf{H}_{6}$ : GCG had an indirect effect on professional performance mediating by affective commitment.

\subsection{KM and Professional Performance Mediating by Affective Commitment}

According to many results of the research, affective commitment also mediates KM on professional performance. The principles of KM which focus on the people, process, and conceptual can be an excellent condition to potentially enhancing affective commitment, which involves the employees' emotional attachment to, identification with, and involvement in the organization [46], and then implicate to increase professional performance reflected in teaching skills, communication skills, personality authority, social skills, technical competence and emotional stability. The studies conducted 
by scholars in various fields also indicated that KM affects affective commitment [58]-[61]. Meanwhile, the research in other contexts carries out by researchers show that affective commitment affects professional performance [47]-[55]. Based on argues and studies above, the seventh hypothesis in this study is:

$\mathbf{H}_{7}$ : $\mathrm{KM}$ had an indirect effect on professional performance mediating by affective commitment.

\section{Methods}

This research uses a quantitative approach to the survey method with using a questionnaire in the form of a Likert scale model with five alternative answers: strongly disagree, disagree, neutral, agree, and strongly agree. The questionnaire makes researchers themselves based on the theoretical dimensions, aspects, or indicators of the experts. GCG questionnaire consists of 10 items with an alpha coefficient $=.938$, KM consists of 10 items with an alpha coefficient $=.909$, affective commitment consists of 9 items with alpha coefficients $=.836$, and professional performance consists of 12 items with an alpha coefficient $=.948$.

The research participants are 375 teachers in Indonesia spreading across three provinces (Jakarta, Banten, West Java) determined by accidental sampling based on participant willingness to fill in the questionnaire at the time the research was conducted [62]. The profile of the research participant is presented in Table 1 . The majority of gender is female (64\%), ages 26 - 35 years $(42.13 \%)$, bachelor education (74.93\%), marital status (76\%), and length of teaching $\leq$ five years $(33,33 \%)$.

Data analysis by path analysis and the path coefficient uses a t-test supported by descriptive statistics. Descriptive analyses were performed by SPSS version 26, while the path analysis by Lisrel 8.80 .
Table 1. Profile of Research Participant

\begin{tabular}{|c|c|c|}
\hline Profile & Amount & Percentage \\
\hline \multicolumn{3}{|c|}{ Gender } \\
\hline Male & 135 & 36 \\
\hline Female & 240 & 64 \\
\hline \multicolumn{3}{|c|}{ Age } \\
\hline$\leq 25$ Year & 48 & 12.80 \\
\hline 26 - 35 Year & 158 & 42.13 \\
\hline $36-45$ Year & 90 & 24 \\
\hline $46-55$ Year & 77 & 20.53 \\
\hline$\geq 56$ Year & 2 & 0.53 \\
\hline \multicolumn{3}{|c|}{ Education } \\
\hline Diploma & 6 & 1.60 \\
\hline Bachelor & 281 & 74.93 \\
\hline Postgraduate & 88 & 23.47 \\
\hline \multicolumn{3}{|c|}{ Status } \\
\hline Married & 285 & 76 \\
\hline Unmarried & 90 & 24 \\
\hline \multicolumn{3}{|c|}{ Length of Teach } \\
\hline$\leq 5$ Year & 125 & 33.33 \\
\hline $6-10$ Year & 90 & 24 \\
\hline $11-15$ Year & 59 & 15.73 \\
\hline$\geq 16$ Year & 101 & 26.93 \\
\hline
\end{tabular}

\section{Finding}

The results of the descriptive statistical analysis for the four variables are presented in Table 2 . The mean values of the four variables from the lowest to the highest in succession are affective commitment (35.06), KM (40.56), GCG (43.19), and professional performance (46.91).

Table 2. Descriptive Statistics

\begin{tabular}{|c|c|c|c|c|c|}
\hline & & GCG & KM & Affective Commitment & Professional Performance \\
\hline \multirow{2}{*}{$\mathrm{N}$} & Valid & 375 & 375 & 375 & 375 \\
\hline & Missing & 0 & 0 & 0 & 0 \\
\hline \multicolumn{2}{|c|}{ Mean } & 43.19 & 40.56 & 35.06 & 46.91 \\
\hline \multicolumn{2}{|c|}{ Median } & 43.00 & 40.00 & 35.00 & 47.00 \\
\hline \multicolumn{2}{|c|}{ Mode } & 40 & 40 & 34 & 48 \\
\hline \multicolumn{2}{|c|}{ Std. Deviation } & 5.232 & 4.751 & 4.234 & 7.557 \\
\hline \multicolumn{2}{|c|}{ Variance } & 27.371 & 22.568 & 17929 & 57.106 \\
\hline \multicolumn{2}{|c|}{ Range } & 31 & 24 & 25 & 42 \\
\hline \multicolumn{2}{|c|}{ Minimum } & 19 & 26 & 20 & 18 \\
\hline \multicolumn{2}{|c|}{ Maximum } & 50 & 50 & 45 & 60 \\
\hline \multicolumn{2}{|c|}{ Sum } & 16195 & 15210 & 13148 & 17590 \\
\hline
\end{tabular}


The results of hypothesis testing with path analysis of the effects of GCG, KM, and affective commitment on professional performance are summarized in Table 3 and visualized in Figures 1 and 2. The hypothesis testing shows that all hypotheses were supported (t-value $>\mathrm{t}$-table at $\alpha$ $=.05$ and .01 ). Therefore the findings of this study are GCG and KM, and affective commitment had a significant direct effect on professional performance, then GCG and KM had a significant direct effect on affective commitment. Besides, the results of this study also showed that GCG and KM had a significant indirect effect on professional performance mediating by affective commitment. Based on result path coefficient, the affective commitment had a direct effect more adequate on professional performance ( .59) then GCG ( .06) and KM ( .32), KM had a direct effect more adequate on affective commitment ( .53) then GCG ( .28), and KM had an indirect effect more adequate on professional performance mediating by affective commitment ( .31) then GCG ( .17).

In Figure 1 and 2, the test results of the model with the goodness of fit statistics show the significant with Chi-Square $=0.000, \mathrm{df}=0, \mathrm{p}$-value $=1.00000>.05$ and RMSEA $=.000<.08$, so that the model tested is fit. This result indicates that empirical data from teachers in Indonesia support the theoretical model being tested.

Table 3. Summary of Path Coefficients and T-values

\begin{tabular}{|c|c|c|c|}
\hline Hypothesis & Path Coefficients & T Value & Hypothesis Testing \\
\hline H1: GCG (X1) on professional performance (Y2) & $.06^{*}$ & 2.01 & Supported \\
\hline H2: KM (X2) on professional performance (Y2) & $.32^{* *}$ & 9.48 & Supported \\
\hline $\begin{array}{c}\text { H3: Affective commitment (Y1) on professional } \\
\text { performance (Y2) }\end{array}$ & $.59^{* *}$ & 16.47 & Supported \\
\hline H4: GCG (X1) on affective commitment (Y1) & $.28^{* *}$ & 6.94 & Supported \\
\hline H5: KM (X2) on affective commitment (Y1) & $.53^{* *}$ & 13.02 & Supported \\
\hline $\begin{array}{c}\text { H6: GCG (X1) on professional performance (Y2) } \\
\text { mediating by affective commitment (Y1) }\end{array}$ & $.17^{* *}$ & 6.40 & Supported \\
\hline $\begin{array}{c}\text { H7: KM (X2) on professional performance (Y2) mediating } \\
\text { by affective commitment (Y1) }\end{array}$ & $.31^{* *}$ & 10.21 & Supported \\
\hline
\end{tabular}

$* \mathrm{p}<.05$

$* * \mathrm{p}<.01$

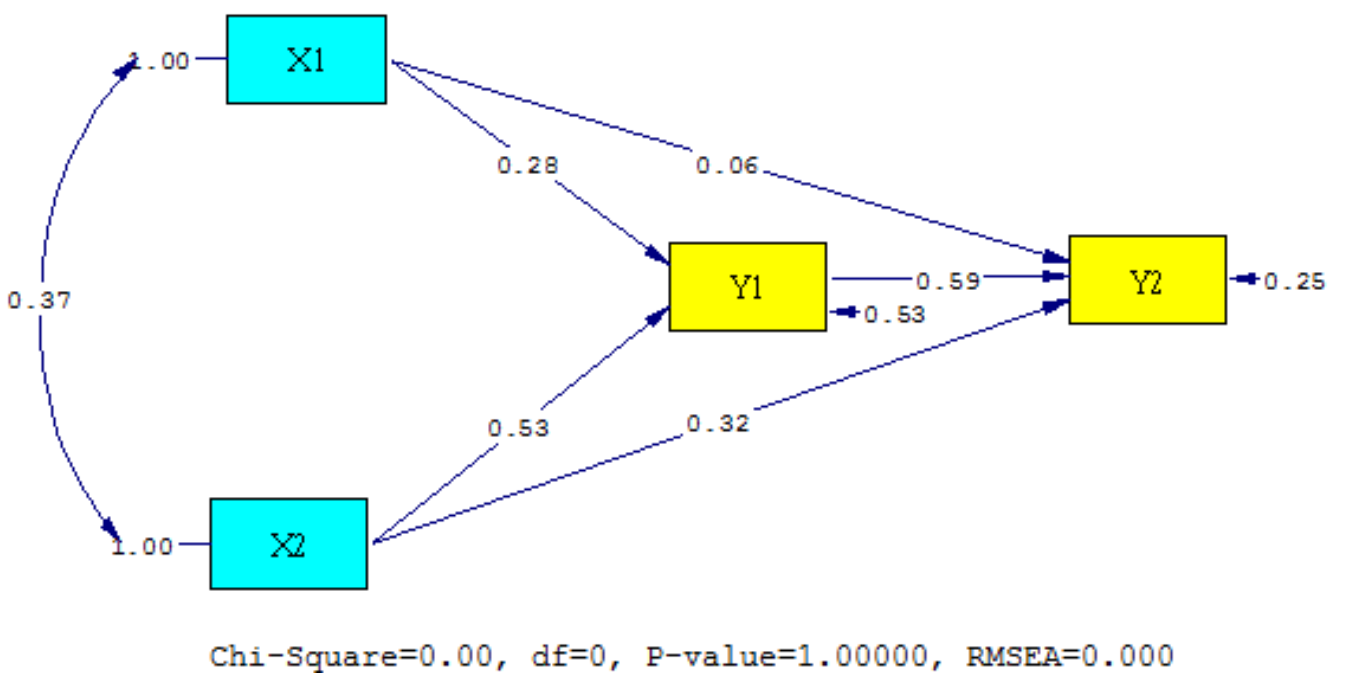

Figure 1. Path Coefficients 


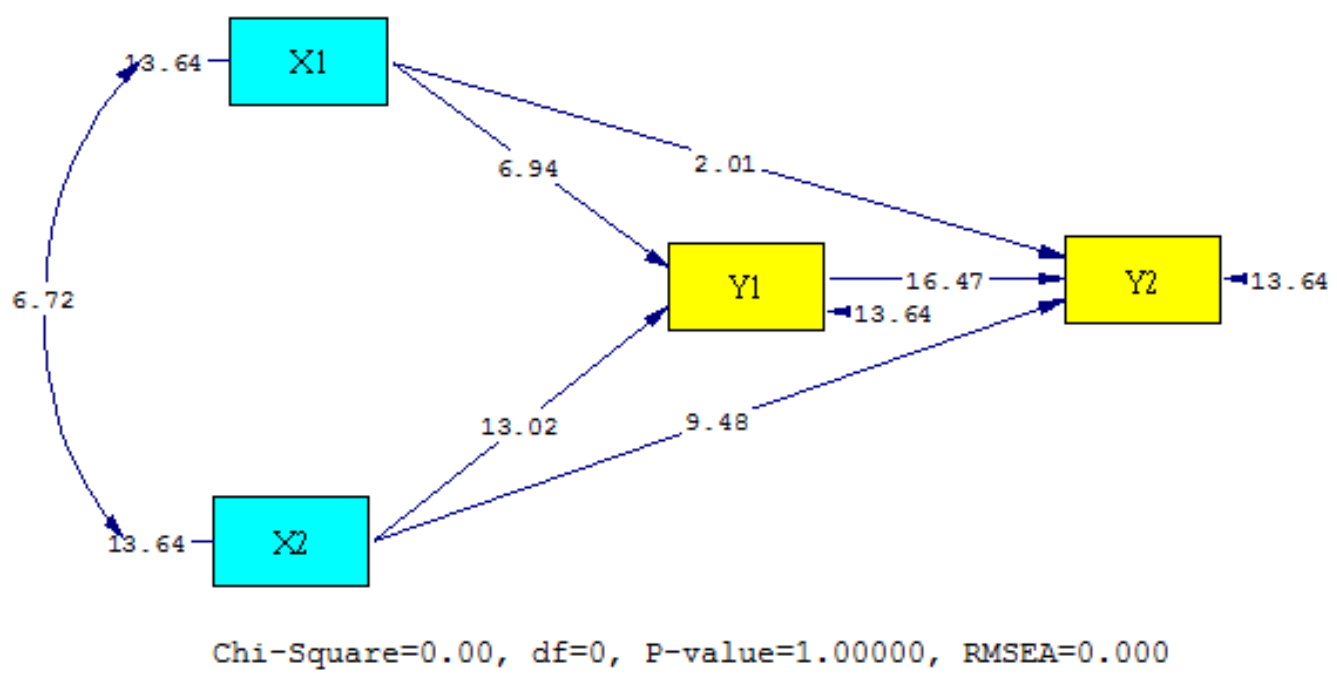

Figure 2. T Values

\section{Discussion}

This research revealed that GCG and KM had a significant effect on professional performance, either directly or indirectly, mediated by affective commitment. The research also created a fit model that the theoretical model was fit with empirical data from the teachers in Indonesia. This finding confirms that GCG, KM, and affective commitment are important determinants for teacher's professional performance. Moreover, affective commitment plays a significant role as a mediator of GCG and KM on professional performance. These findings were consistent and confirmed other studies and research results used as a reference to develop this research hypothesis. For example, several studies concluded that professional performance affected by GCG [18]-[23], KM [30]-[39], and affective commitment [47]-[55]. As a consequence of this evidence, school leaders need to maintain and manage GCG, KM, and affective commitment seriously through various policies, approaches, and strategies that are relied on to increase the teacher's professional performance. In the case of GCG, school leaders should develop a school culture feasible for growth in various principles of GCG, such as transparency, accountability, responsibility, independence, and fairness [17]. For KM, school leaders need to uphold KM principles that concern the people, process, and conceptual. In the affective commitment context, school leaders urgent to prepare good condition which stimulates the teachers more intense to participated and involved in any organizations activities.

This study also found that effective commitment plays a vital role as mediators in GCG and KM effect on professional performance. This evidence in line with studies concluded that GCG influences affective commitment [56][57], KM influences affective commitment [58]-[61], and affective commitment affects professional performance [47]-[55]. This finding reveals empirical facts that the existence of affective commitment is very important to be considered in the context of increasing professional performance through GCG and KM. Any efforts to enhance professional performance will be better if done by improving GCG and KM with support increasing affective commitment. As a consequence that the school leaders need to maintain and develop optimally affective commitment through various possible approaches, methods, and strategies.

Overall, this study confirms several studies in various countries, industrial, occupational sectors, and organizations. It is also finding a new empirical model of the effect of GCG and KM on professional performance mediated by affective commitment based on the data from teachers in Indonesia. This model can adopt a discourse or reference among researchers and practitioners to develop better professional performance models in the future and various organization's contexts.

\section{Conclusions}

This research proves that GCG and KM had a significant effect on professional performance, either directly or indirectly, mediated by affective commitment. The study also was found a fit research model about the effect of GCG and KM on professional performance mediated by affective commitment with the research field of the teachers in Indonesia. This model can be adopted among researchers and practitioners as references or discourse or a strategy for enhancing professional performance in various contexts and research fields. The model can be further developed for the researcher and expanded into new research with more participants, adding variables, other indicators, and another statistical approach, such as structural equation modeling (SEM). For practitioners, the model can be used to increase the professional performance of teachers or employees through improving GCG, KM, and affective commitment. 


\section{Acknowledgments}

We are very grateful to the teachers in Indonesia who volunteered to spend their time and full dedication to responding to every statement item in the questionnaire completely and entirely to be used as research material in this article. May this willingness and commitment be a contribution to the development of science that can improve civilization.

\section{REFERENCES}

[1] Hoy, W. K., \& Miskel, C.G. (2013). Educational Administration: Theory, Research, and Practice. New York: McGraw-Hill Company.

[2] Senge, P.M. (1990). The fifth discipline: The art and the practice of the learning organization. New York: Doubleday.

[3] Ivancevich, J. M., Konopaske, R., \& Matteson, M. T. (2014). Organizational behavior \& management. Tenth edition. New York: McGraw Hill Education.

[4] Colquitt, J. A., Lepine, J. A., \& Wesson, M. J. (2015). Organizational behavior: improving performance and commitment in the workplace 4th edition. New York: McGraw Hill Education Limited.

[5] Byars, L.L., Rue, L.W., \& Ibrahim, N.A. (2016). Human resource management 11th ed. New York: McGraw-Hill Education.

[6] Daft, R. L. (2014). New era of management. $11^{\text {th }}$ edition. New Zealand: South-Western Cengage Learning.

[7] Pratte, R., \& Rury, J. L. (1991). Teachers, professionalism, and craft. Teachers College Record, 93(1), 59-72.

[8] Rulandari, N. (2017). The effect of supervision and professionalism on staff performance at the office of social affairs in East Jakarta Administrative City. International Journal of Humanities and Social Science, 7(2), 184-192.

[9] Hammer, D.P., Berger, B.A., Beardsley, R.S., \& Easton, M.R. (2003). Student professionalism. Am J Pharm Educ, 67: 96.

[10] Grady, M.P., Helbling, K.C., \& Lubeck, D.R. (2008). Teacher professionalism since a nation at risk. Phi Delta Kappan, 89, 603-604.

[11] Glickman, C.D., Gordon, S. P., Ross-Gordon, J. M. (2010). Supervision and instructional leadership, eighth edition. Boston: Pearson Education, Inc.

[12] Hey, R.B. (2017). What Are the Principles of Good Governance? In Performance Management for the Oil, Gas, and Process Industries, Elsevier Science, 91-105.

[13] Lukviarman, N. (2016). Corporate governance: Menuju penguatan konseptual dan implementasi di Indone-sia. Jakarta: Era Adicitra Intermedia.

[14] Sukariana, I.W., \& Darma, G.S. (2015). Peran audit dalam pengendalian internal serta pengungkapan kerugian material untuk good corporate governance. Jurnal Manajemen \& Bisnis, 12(2), 181-194.

[15] Guna, W.I., \& Herawaty, A. (2010). Pengaruh mekanisme good corporate governance, independensi auditor, kualitas audit dan faktor lainnya terhadap manajemen laba. Jurnal Bisnis dan Akuntansi, 12(1), 53-68.

[16] Liu, Y., Luo, Y., \& Liu, T. (2009). Governing buyer-supplier relationships through transactional and relational mechanisms: Evidence from China. J. Oper. Manag, 27(4), 294-309.

[17] Svärd, P. (2017). Accountability, transparency, and the role of information management. In Enterprise Content Management, Records Management, and Information Culture Amidst e-Government Development, 83-96.

[18] Kima, D., Kima, J., Byunb, Y., \& Chunc, S. (2013). A Study on the Effect of Governance Adequacy on the Corporate Performance. Procedia - Social and Behavioral Sciences, 107, 59-66.

[19] Sanchia, M. I., \& Zen, T. S. (2015). Impact of good corporate governance in corporate performance. International Journal of Management and Applied Science, 1(9), 102-106.

[20] Ahmed, E., \& Hamdan, A. (2015).The impact of corporate governance on firm performance: evidence from Bahrain Bourse. International Management Review, 11(2), 21-37.

[21] Mahrani, M., \& Soewarno, N. (2018). The effect of good corporate governance mechanism and corporate social responsibility on financial performance with earnings management as a mediating variable. Asian Journal of Accounting Research, 3(1), 41-60.

[22] Aktan, B., Turen, S., Tvaronavičienė, M., Celik, S., \& Alsadeh, H. A. (2018). Corporate governance and performance of the financial firms in Bahrain. Polish Journal of Management Studies, 17(1), 39-58.

[23] Haq, S.U., Gu, D., Liang, C., \& Abdullah, I. (2019). Project governance mechanisms and the performance of software development projects: Moderating role of requirements risk. International Journal of Project Management, 37, 533-548.

[24] Ciftci, I., Tatoglu, E., Wood, G., Demirbag, M., \& Zaim, S. (2019). Corporate governance and firm performance in merging markets: Evidence from Turkey. International Business Review, 28, 90-103.

[25] Jackson, S.E., Shculer, R.S., \& Werner, S. (2009). Managing human resources. $10^{\text {th }}$. United States of America: South-Western Cengage Learning.

[26] Armstrong, M. (2009). A handbook of human resource management practice. London: Kogan Page.

[27] [26] Noe, R .A., Hollenbeck, J. R., Gerhart, B., \& Wright, P. M. (2015). Human resource management: Gaining a competitive advantage. 9th edition. New York: McGraw-Hill Education.

[28] Slocum, J.W., Jackson, S.E., \& Hellriegel, D. (2008). Competency-based management. Mason: Thomson Higher Education.

[29] Rooney, D., Hearn, G., \& Ninan (Eds). (2006). Handbook on 
the knowledge economy. Northampton, MA: Edward Elgar Publishing.

[30] Davenport, T. H. (1997). Ten principles of knowledge management and four case studies. Knowledge and Process Management, 4(3), 187-208.

[31] Torabi, M.H.R., Kyani, A., \& Falakinia, H. (2016). An investigation of the impact of knowledge management on human resource performance in the management of Keshavarzi bank branches in Tehran. Procedia-Social and Behavioral Sciences, 230, 471-481.

[32] Setyanti, S.W.L.H., \& Farida, L. (2016). The effect of knowledge sharing on business performance moderated by innovation products in the small and medium enterprises in Indonesia. International Journal of Scientific \& Technology Research, 5(11), 209-211.

[33] Garrick, J., \& Chan, A. (2017). Knowledge management and professional experience: the uneasy dynamics between tacit knowledge and performativity in organizations. Journal of Knowledge Management, 21(4), 872-884.

[34] Widjajani, R., Nimran, U., Utami, H.N. (2017). The effect of trust, job involvement, organizational commitment, knowledge sharing behavior on employee performance. International Journal of Business and Management Invention, 6(11), 69-75.

[35] Khanal, L., \& Poudel, S.R. (2017). Knowledge management, employee satisfaction, and performance: Empirical evidence from Nepal. Saudi Journal of Business and Management Studies, 2(2), 82-91.

[36] Ghanbari, S., \& Dastranj, M. (2017). The effect of knowledge management on the performance of personnel of Hormozgan Payame Noor University. Journal Socialomics, an Open Access Journal, 6(4), 1-4.

[37] Alyoubi, B., Hoque, R., Alharbi, I., Alyoubi, A., \& Almazmomi, N. (2018). Impact of knowledge management on employee work performance: evidence from Saudi Arabia. The International Technology Management Review, $7(1), 13-24$.

[38] Gyemang, M.D., \& Emeagwali, O.L. (2020). The roles of dynamic capabilities, innovation, organizational agility, and knowledge management on competitive performance in the telecommuni-cation industry. Management Science Letters, $10,1533-1542$.

[39] Huie, C. P., Cassaberry, T., \& Rivera, A. K. (2020). The impact of tacit knowledge sharing on job performance. International Journal on Social and Education Sciences, 2(1), 34-40.

[40] Al-Abbadia, L., Alshawabkeha, R., \& Rummana, A.A. (2020). Knowledge management processes and innovation performance: The moderating effect of employees' knowledge hoarding. Management Science Letters, 10, 1463-1472.

[41] Newstrom, J. W. (2015). Organizational behavior: human behavior at work. Fourteenth edition. New York: McGraw Hill Education.

[42] Nelson, D. L., \& Quick, J. C. (2006). Organizational behavior, foundations, realities \& challenges. Ohio: Thomson.
[43] Gibson, J. L., Donnelly, J. H., Ivancevich, J. J. M., \& Konopaske, R. (2009). Organizational behavior, structure, processes. New York: McGraw Hill Education.

[44] Kreitner, R., \& Kinicki, A. (2010). Organizational behavior: key concepts, skills \& best practices. New York: McGraw-Hill Irwin.

[45] Beardwell, J., \& Thompson, A. (2014). Human resource management: A contemporary approach. $8^{\text {th }}$ edition. United Kingdom: Pearson Education Limited.

[46] Robbins, S. P., \& Judge, T. A. (2015). Organizational behavior. $16^{\text {th }}$ edition. Essex: Pearson Education Limited.

[47] Meyer, J. P., \& Allen, N.J. (1991). A three-component conceptualization of organizational commitment. Human Resource Management Review, 1, 61-89.

[48] Hadziahmetovic, N., \& Dinc, M. S. (2017). The mediating role of affective commitment in the organizational rewards-organizational performance relationship. International Journal of Human Resource Studies, 7(3), $105-130$

[49] Renyut, B.C., Modding, H.B., Bima, J., \& Sukmawati, S. (2017). The effect of organizational commitment, competence on job satisfaction, and employee performance in Maluku governor's office. IOSR Journal of Business and Management (IOSR-JBM), 19(11), 18-29.

[50] Destari, Y., Lumbanraja, P., \& Absah, Y. (2018). The influence of work satisfaction on employee's performance with organizational commitment as an intervening variable at the mining and energy agency of north Sumatera. International Journal of Research \& Review, 5(12), 355-364.

[51] Khunsoonthornkit, A., \& Panjakajornsak, V. (2018) Structural equation model to assess the impact of learning organization and commitment on the performance of research organizations. Kasetsart Journal of Social Sciences, $39,457-462$

[52] Fajrin, D., Saragih, B., \& Indratjahjo, H. (2018). The effect of organizational commitment and organizational culture on employee performance through behavior civilization organizations of teachers and employees Madrasah Bbtidaiya Nurussyifa Indonesia. International Journal of Business and Applied Social Science (IJBASS), 4, 3, 24-49.

[53] Lin, L., \& Shiqian, W. (2018). The mediating effect of organizational commitment on leadership type and job performance. Journal of World Economic Research, 7(1), $14-20$.

[54] Metin, K., \& Asli, K. (2018). The relationship between organizational commitment and work performance: A case of industrial enterprises. Journal of Economic and Social Development (JESD), 5(1), 46-50.

[55] Suharto, Suyanto, \& Hendri, N. (2019). The impact of organizational commitment on job performance. International Journal of Economics and Business Administration, 7, 2, 189-206.

[56] Sungu, L.J., Weng, Q., \& Xu, X., (2019). Organizational commitment and job performance: Examining the moderating roles of occupational commitment and transformational leadership. International Journal Selection 
Assessment, 00, 1-11.

[57] Purwanto, S.K. (2015). The effect of organizational governance on the performance and commitment of the lecturers. Public Policy and Administration Research, 5(1), $35-42$.

[58] Aini, N., \& Maswanto. (2019). Determinants of good corporate governance and its implications on organizational commitments (empirical study on employees of Government-Owned Islamic Banks in DKI Jakarta Province) in International Conference on Economics, Management, and Accounting, KnE Social Sciences, 948-973.

[59] Almasi, M., Falahati, A., \& Rostami, A. (2013). The relation between knowledge management and organizational commitment. Elixir Edu. Tech. 64, 18976-18981.

[60] Li, J., Yuan, L., Ning, L., \& Li-Ying, J. (2015). Knowledge sharing and affective commitment: the mediating role of psychological ownership. Journal of Knowledge Management, 19(6), 1-43.

[61] Ikechukwu, D., \& Callystus, A. (2018). Knowledge management and organizational commitment. International Journal of Business and Management Invention (IJBMI), 7(3), 19-24.

[62] Vidyani, N. P., \& Desiana, P. M. (2018). The effect of knowledge sharing on affective commitment: the mediation role of competency development of gen y employees at PT PP (Persero), Tbk head office. 12th International Conference on Business and Management Research (ICBMR 2018), Advances in Economics, Business and Management Research, 72, 105-110.

[63] Widodo. (2019). Metodologi penelitian populer \& praktis. Depok: Rajawali Pers. 